\title{
THE BAN ON VEILS IN EDUCATION INSTITUTIONS: JURISPRUDENCE OF THE EUROPEAN COURT OF HUMAN RIGHTS
}

\begin{abstract}
Ivana Radačić ${ }^{*}$
Summary: Debate on wearing Islamic headscarves in the public sphere, including in education institutions, has been one of the most heated debates in today's Europe. The question of the relationship between human rights and the wearing of an Islamic headscarf in education institutions has been posed in many national and international jurisdictions, including before the European Court of Human Rights. This paper explores the Court's approach to bans on wearing Islamic headscarves in education institutions by analysing its case law on the issue. Analysis is focused on the Court's interpretation of the principle of secularism/neutrality and gender equality. The author criticises the Court's overly differential approach, arguing that the principles of equality and secularism have been interpreted in a paternalistic and simplistic manner.
\end{abstract}

\section{Introduction}

Debate on veils ${ }^{1}$ has been one of the most heated discussions in today's Europe (and more broadly) among men and women, decision-makers and 'ordinary people', academics ${ }^{2}$ and non-academics, Muslims and non-Muslims, religious and non-religious people. Discussions have been going on in governments and parliaments, university classrooms, private homes, academic papers, newspapers, over the internet, and in coffee bars. Never has any other garment (including other religious dress) been so extensively discussed, and given such significance and multiplicity of meaning.

The veil has acquired meanings (attributed both by the wearer and observer) that go far beyond the choice of dress for women, even if the debate is predominantly framed in terms of women's rights and gender equality. The veil (un)covers not only the bodies of women who wear it,

\footnotetext{
"Ivana Radačić, PhD in law; research assistant, Ivo Pilar Institute of Social Sciences, Croatia.

1 I use 'veiling' as a generic term to include the hijab, niqab and burqa. See G Anwar and L McKay, 'Veiling' Encyclopaedia of Islam and the Muslim World vol 2 (Macmillan, New York 1994) 721-722.

2 A wide range of disciplines have contributed to these discussions: politics and political theory, law and human rights, women's studies, post-colonial studies, Islamic studies.
} 
but also the issues of national identity, citizenship, integration, pluralism, multiculturalism, liberalism, secularism, fundamentalism, Islamophobia and human rights. As McGoldrick writes, 'the headscarf-hijab debate is thus part of a broader question that is not new, but which is becoming more acute - how do people who disagree over profoundly different matters live together? ${ }^{3}$

Indeed, the veil has been the subject of profound disagreement. Even women, and among them feminist women, disagree on the symbolic meaning of veiling and its relation to gender equality and the rights of women, their position being influenced by many factors, including race and ethic origin, class, religious affiliation, place of residence, and political orientation. Some women argue that women should be 'set free' of this 'patriarchal' practice, even if they need to be forced to do so, ${ }^{4}$ others are concerned about the way the principle of gender equality has been (ab)used to restrict women's choices and to promote other suspect aims, seeing forced unveiling as problematic as forced veiling, ${ }^{5}$ while yet others claim that women have a human right to wear the veil, which cannot be limited to the abstract principles of gender equality and secularism (which, in their view, serve anyway as a cover for Islamophobia).

Particularly problematic is the question of wearing (different kinds of) veil and other religious symbols in schools, schools being "miniature "communities of citizens", where pupils learn the principles of public citizenship. ${ }^{6}$ The questions raised are: what types of veils (if any) should be prohibited; should prohibitions cover only teachers or pupils, or should they extend even to university students; and what roles do human rights principles have? Is there a right to wear a veil (any kinds or only some), or can it be prohibited for the sake of the protection of the rights of others? Precisely which rights are at stake?

\footnotetext{
3 D McGoldrick, Human Rights and Religion: The Islamic Headscarf Debate in Europe (Hart Publishing, Oxford 2006).

4 This is the position of some liberal, Western women, some of whom define themselves as feminist, which has been heavily criticised by many Muslim, feminist and non feminist, women. It is interesting to note that these women do not discuss their own (patriarchal) dress and cultural practices with the same passion and vigour.

5 This is the category I fall into. While it is very difficult for me to understand (different) meanings of the practice, or the life experiences of Muslim women who wear (different forms of) the veil (or who do not wear it and are harassed for that reason), I can grasp the complexities of the problem, the multiple meaning of veiling, the context of discrimination against Muslims, Islamophobia, the possibility of abusing the principle of gender equality for suspect reasons, and the dangers of portraying women as victims. This is the position from which I critique the Court's judgments.

6 C Laborde, 'Secular Philosophy and Muslim Headscarves in Schools' (2005) 13 (3) Political Philosophy 305, 326.
} 
The question of the relationship between human rights and wearing the veil in education institutions has been posed in many national ${ }^{7}$ and international jurisdictions. ${ }^{8}$ The European Court of Human Rights (hereinafter the Court) faced this question in cases taken by Turkish students challenging bans preventing them from wearing the headscarf at universities, ${ }^{9}$ and in the case against Switzerland taken by a primary school teacher challenging the ban imposed on her in a primary state school. ${ }^{10}$ This paper explores the Court's approach to bans on wearing Islamic headscarves in education institutions. The analysis is focused on the Court's interpretation of the principle of secularism/neutrality and gender equality.

\section{Description of cases}

\subsection{Prohibitions on teachers: Dahlab v Switzerland}

The case was decided on admissibility only in 2001. The applicant was a primary school teacher, teaching 4-8 year-old-children at a state school in a Geneva Canton. She started to wear the Islamic headscarf a year after being appointed a teacher, toward the end of the academic year $1990 / 91 .{ }^{11}$ For the four years of wearing the headscarf she had no problems, there being no objections from the school or education authorities. There was never any complaint from parents or pupils. However, in June 1996, the Director General for Primary Education requested the applicant to stop wearing the headscarf, considering such conduct contrary to Section 6 of the Education Act, which mandates respect of pupils and parents' religious and political beliefs. ${ }^{12}$ The applicant appealed first to the Geneva Cantonal Government, and then to the Federal Court, but her appeals were dismissed. Before the Federal Court, she invoked viola-

\footnotetext{
7 See, for example, the Begum case in the UK, which concerned a pupil who was prohibited from wearing a niqab in a state school: $R$ (Shabina Begum) $v$ Headteacher and Governors of Denbigh High School [2006] UKHL 15. See also the Lund case in Germany, which concerned a primary school teacher wearing a headscarf-hijab (Federal Constitutional Court, judgment of 24 September 2003, BVerfG, 2 BvR 1436/02 <www.bverfg.de $>$ ). For an overview of comparative practices, see McGoldrick (n 3).

8 See, for example, Committee on the Elimination of All Forms of Discrimination against Women, Rahime Kayhan v Turkey, Communication No/ 8/2005, CEDAW/C/34/D/8/2005; Dahlab v Switzerland (dec) (App no 42393/98) ECHR 2001-V; Leyla Sahin v Turkey (App no 44774/98) 29 June 2004 and [GC] ECHR 2005.

9 Leyla Sahin $v$ Turkey, ibid.

10 Dahlab v Switzerland (n 8).

11 The applicant converted to Islam from Catholicism, which was emphasised both in the domestic courts' decisions and in the Court's decision.

12 Section 6 of the Cantonal Public Education Act of 6 November 1940 prescribes: 'The public education system shall ensure that the political and religious beliefs of pupils and parents are respected' Dahlab $v$ Switzerland (n 8) 457.
} 
tion of her freedom of religion. However, the court held that "prohibition of the wearing of "powerful" religious symbols"13 was based in law, served the legitimate aims of ensuring denominational neutrality in schools, and was necessary in a democratic society for the protection of the rights of others (pupils in her class, the rest of the school and their parents) and of public order and public safety,,$^{14}$ in view of her special status as a teacher of young children, and a civil servant.

Before the European Court of Human Rights, the applicant argued that the prohibition amounted to a violation of the freedom of religion (Article 9) and the right to non-discrimination on the basis of sex (Article 14 in conjunction with Article 9). The Government claimed that the measure was necessary to protect the religious freedoms of parents and students and to prevent religious conflict in schools, and that it was proportionate, taking into account the applicant's special roles as civil servant. ${ }^{15}$ The applicant accepted the principle of denominational neutrality as a legitimate aim, but held that it requires only that teaching should be independent of religious faith and does not prevent teachers from holding belief. She also maintained that she never wanted to influence her pupils religiously and that there was no evidence of any such impact.

The Court first analysed the Article 9 claim. It reiterated that freedom of thought, conscience and religion, as enshrined in Article 9 of the Convention, represents one of the foundations of a democratic society within the meaning of the Convention and that this freedom implies freedom to manifest religion, but that in 'democratic societies, in which several religions coexist within one and the same population, it may be necessary to place restrictions on this freedom in order to reconcile the interests of the various groups and ensure that everyone's beliefs are respected.' It accepted that in the case at issue there was an interference with the manifestation of the applicant's belief, and then proceeded to assess whether it could be justified; in other words, whether the interference was in accordance with law and 'necessary in democratic society.' The Court held that the interference was in accordance with law, as in

13 My emphasis. It is to be noted that the wearing of 'discrete' religious symbols by teachers, such as 'small pieces of jewellery' (eg the cross) was not considered as contrary to the principle of denominational neutrality and was hence not prohibited. Dahlab v Switzerland, ibid.

14 There was also the following reference to gender equality in the Federal Court judgment: 'It must also be acknowledged that it is difficult to reconcile the wearing of a headscarf with the principle of gender equality ... which is a fundamental value of our society enshrined in a specific provision of the Federal Constitution (Article $4 \S 2$ ) and must be taken into account by schools.' Ibid.

15 They also maintained that the applicant had the choice to teach at private schools which were not subjected to the requirement of neutrality. However, the applicant argued that she had no realistic alternatives, since there were only very few private schools for children in the age group she taught, and all were of a religious orientation that she did not share. 
its view the law was sufficiently precise, even though there was no law explicitly prohibiting teachers from wearing headscarves. ${ }^{16}$ It also held that it served the legitimate aims of protecting the rights of others and of public order, accepting that the wearing of a headscarf by a teacher may threaten both the right of her pupils and their parents, and public order, and that it was proportionate in the circumstances of the case. ${ }^{17}$ In respect of the impact that 'a powerful external symbol such as the wearing of a headscarf may have on the freedom of conscience and religion of very young children', the Court held:

it cannot be denied outright that the wearing of a headscarf might have some kind of proselytising effect, seeing that it appears to be imposed on women by a precept which is laid down in the Koran and which, as the Federal Court noted, is hard to square with the principle of gender equality. It therefore appears difficult to reconcile the wearing of an Islamic headscarf with the message of tolerance, respect for others and, above all, equality and non-discrimination that all teachers in a democratic society must convey to their pupils. ${ }^{18}$

The Court concluded that 'having regard, above all, to the tender age of the children for whom the applicant was responsible as a representative of the State, ${ }^{19}$ the Geneva authorities did not exceed their margin of appreciation and that the measure they took was therefore not unreasonable. In the light of these considerations and those set out by the Federal Court, the Court held that the prohibition was 'necessary in a democratic society' and dismissed the claim as manifestly ill-founded.

The Court then analysed the Article 14 claim. The applicant argued that the prohibition of wearing the headscarf and other 'visible religious symbols' constituted discrimination on the basis of sex, in that 'a man belonging to the Muslim faith could teach at a State school without being subject to any form of prohibition, whereas a woman holding similar beliefs had to refrain from practising her religion in order to be able to teach. ${ }^{20}$ The Court reiterated its principles 'that the advancement of the equality of the sexes is today a major goal in the member States of the

\footnotetext{
16 The following sources were fond relevant: the above-mentioned Section 6 of the Canton of Geneva Public Education Act; Section 120(2) of the Public Education Act, which provides: 'Civil servants must be lay persons; derogations from this provision shall be permitted only in respect of university teaching staff; and Article $27 \S 3$ of the Federal Constitution of 29 May 1874, which reads: 'It shall be possible for members of all faiths to attend State schools without being affected in any way in their freedom of conscience or belief Dahlab $v$ Switzerland (n 8) 457.

17 It was held relevant that the applicant was a representative of the state, that she was teaching very young children, and that there were alternatives available to her.

18 N 7463.

19 Ibid.

$20 \quad$ N 7463.
} 
Council of Europe' and that 'very weighty reasons would have to be advanced before a difference in treatment on the ground of sex could be regarded as compatible with the Convention'. ${ }^{21}$ However, as in other indirect discrimination cases,${ }^{22}$ the formula was not really applied. ${ }^{23}$ Instead of focusing on the effect of the measure, the Court looked at its intent. It held:

... the measure by which the applicant was prohibited, purely in the context of her professional duties, from wearing an Islamic headscarf was not directed at her as a member of the female sex but pursued the legitimate aim of ensuring the neutrality of the State primaryeducation system. Such a measure could also be applied to a man who, in similar circumstances, wore clothing that clearly identified him as a member of a different faith. ${ }^{24}$

It therefore concluded that there was no discrimination and held the claim was manifestly ill-founded.

\subsection{Prohibitions on students: Leyla Sahin v Turkey}

This case, the only 'Islamic headscarf case' decided on merits, was adjudicated by the $4^{\text {th }}$ section of the Court in 2004 and by the Grand Chamber in $2005 .{ }^{25}$ The applicant, then a student at Istanbul University, was refused entry to lectures, access to examination and enrolment to courses, for wearing a headscarf, following the issuance by the Vice Chancellor of a circular prohibiting the wearing of a headscarf (or beard) at the university campus. Before the issuance of the circular, the applicant freely wore the headscarf both at Istanbul University and before that at Bursa University for her first four years of university education. As she refused to follow the

\footnotetext{
21 Ibid 464.

22 The applicant did not argue that the distinction was made explicitly on the basis of sex, but that it had a disparate impact on Muslim women who wore the headscarf, and hence her claim could best be classified as an indirect discrimination claim.

23 While the Court has suggested in many cases that indirect discrimination is covered by the Article, it was only in Zarb Adami v UK (App no 17209/02) ECHR 2006 that the Court first found an indirect discrimination claim established. Prior to that case, in indirect discrimination claims, it has either referred to the legitimate aim/intent of the challenged measure, or to a high standard of proof, under which statistics are not sufficient to establish prima facie discrimination.

$24 \quad \mathrm{~N} 7464$

25 Upon the delivery of the judgment by the $4^{\text {th }}$ Chamber which found no violation of the Convention (29 June 2004), the applicant referred the case (on 27 September 2004) to the Grand Chamber to hear the case according to Article 43 of the Convention, which accepted the jurisdiction (on 10 November 2004). Article 43(2) states that a panel of five judges of the Grand Chamber shall accept such requests if the case raises a serious question affecting the interpretation or application of the Convention or its protocols, or a serious issue of general importance for the Protection of Human Rights and Fundamental Freedoms (opened for signature 4 November 1950, entered into force 3 September 1953) CETS No 005, 213 UNTS 221 (ECHR).
} 
dress code, disciplinary proceedings were initiated against her and she was issued with a warning. She was later suspended for taking part in a protest against the dress code. Penalties were subsequently lifted under the Amnesty Law. In the meantime, following her unsuccessful application to the Istanbul Administrative Court to set aside the circular (which was later affirmed by the Supreme Administrative Court), the applicant abandoned her studies in Turkey and enrolled at Vienna University.

The applicant argued that her right to respect for private life (Art 8), freedom of religion (Art 9), freedom of expression (Art 10), right to education (Protocol 1, Art 2) and right to non-discrimination on the basis of religion (Art 14) were violated. The government argued that interference with the applicant's rights, based on the (Constitutional) principle of secularism and gender equality, was 'necessary in democratic society' for the protection of the rights of others and of public order. The Chamber analysed her complaint under Art 9 and found no violation, while holding that no separate issue arose under other Articles. The Grand Chamber first analysed the claims under Article 9 and then under Article 2 of Protocol 1, holding that the same considerations were applicable under both claims. The discrimination claim was also analysed by the Grand Chamber, but was dismissed.

The Grand Chamber found that there was interference with Art 9, accepting (the Chamber's finding) that by 'wearing the headscarf, she was obeying a religious precept and thereby manifesting her desire to comply strictly with the duties imposed by the Islamic faith. ${ }^{26}$ It then analysed whether interference with her manifestation of religion could be justified under Art 9(2). The Court found that interference was in accordance with law, as in its opinion the legal source of the prohibition was sufficiently foreseeable and accessible, even though at the time in question there was no written law explicitly prohibiting the wearing of an Islamic headscarf. ${ }^{27}$ It then proceeded to assess whether interference was "necessary

\footnotetext{
26 Leyla Sahin v Turkey (App no 44774/98) [GC] ECHR 200578.

27 The relevant law on university students' dress code (Transitional Section 17 of Law no 2547) stipulated that the choice of dress is free, provided that it does not contravene the laws in force. The Turkish Supreme Court, in its judgment of 9 April 1991, interpreted this provision as prohibiting students from wearing the veil, since it saw wearing the veil as contrary to the constitutional principle of secularism. Before that, on 7 March 1989, it repealed Transitional Section 16 of the Higher-Education Act which provided that a veil or headscarf covering the neck and head could be worn on university premises out of religious conviction. The applicant argued that the circular in question was contrary to law (no 2547) and that it could not be argued that a valid legal basis for that regulation was the case law of the Supreme Court. This was because the Court had no jurisdiction to create new law, a power reserved for the Parliament which had never banned headscarves in higher education (even after the judgments of the Supreme Court). The Court held that 'law' must be understood to include both statutory and judge-made law, and found that there was a legal basis for interference, namely Transitional Section 17 of Law no 2547, in the light of the relevant domestic
} 
in a democratic society', in other words, whether it pursued a legitimate aim and whether the means used were proportionate to the aim.

The Grand Chamber first restated the general principles, holding that states have a wide margin of appreciation in respect of regulating the wearing of religious symbols in education institutions, "especially in view of the diversity of the approaches taken by national authorities on the issue. ${ }^{28}$ The Court then repeated the findings in Dahlab that 'in democratic societies the State is entitled to place restrictions on the wearing of the Islamic headscarf if it was incompatible with the pursued aim of protecting the rights of others and public order and public safety' and, what judge Tulkens defined as the most problematic aspect in Dahlab, ${ }^{29}$ that the 'Islamic headscarf could not easily be reconciled with the message of tolerance, respect for others and, above all, equality and non-discrimination. ${ }^{30}$ The Court did not, however, mention the differences between the Dahlab case and the Leyla Sahin case, and how crucial the fact was that Dahlab was a teacher in a state school (and hence a representative of the state and a civil servant who had voluntarily accepted an employment contract) who taught very young children in the state school, who were allegedly susceptible to influence.

The Grand Chamber then analysed the justification for interference in the case at issue. Following the Chamber's approach, it accepted that restrictions were based on the principles of secularism and equality, which, it held, were also the values underpinning the Convention. Particular emphasis was placed on gender equality and the rights of women. The Grand Chamber restated the Chamber's reasoning that gender equality was "one of the key principles underlying the Convention and the goal to be achieved by members States of the Council of Europe, ${ }^{31}$ and noted 'the emphasis placed in the Turkish constitutional system on the protection of the rights of women. ${ }^{32}$ It then restated the Chamber's fears regarding the impact that

case law. It also found the law sufficiently accessible and foreseeable. For a critique of the Court's approach, see B Cali, 'International Justice before the European Court of Human Rights: Between Legal Cosmopolitanism and Society of States' in MB Dembour and T Kelly (eds), Limits of International Justice: Social and Legal Pesepctives (Cambridge University Press, forthcoming 2007); F Benli, 'Legal Evaluation of the Ban Imposed on University Students who Wear the Headscarf Subsequent to the ECtHR's Ruling in Leyla Sahin $v$ Turkey' < http://www.ihrc.org.uk/file/LEGAL_EVALUATION.doc> accessed 20 July 2007.

28 N 26109

29 Dissenting opinion of Judge Tulkens. Ibid.

30 Ibid 12.

31 My emphasis. N 26115.

32 Ibid. Turkey has, however, often been criticised by UN human rights bodies, including by CEDAW Committee, for the situation in respect of women's rights. See eg CEDAW Committee, 'Consideration of Combined Fourth and Fifth Periodic Report of Turkey' (8 September 2003) UN Doc CEDAW/C/TUR/4-5. 
wearing such a symbol, which is presented or perceived as a compulsory religious duty, may have on those who choose not to wear it in a country in which the majority of population adhere to the Islamic faith...especially since...this religious symbol has taken on political significance in Turkey in recent years... and [in light of] extremist political movements in Turkey which seek to impose on society as a whole their religious symbols... ${ }^{33}$

It therefore concluded that regulations constitute a measure intended to achieve the legitimate aims of protecting the 'rights and freedoms of others' and of the 'maintenance of public order,' and 'thereby to preserve the pluralism in the university. ${ }^{34}$

The Court then analysed the proportionality of the measure. It placed particular emphasis on the 'facts' that 'students were free, within the limits imposed by educational organisational constraints, to manifest their religion in accordance with habitual forms of Muslim observance ${ }^{35}$ and that "university authorities sough to adapt the evolving situation in a way that would not bar access to the university to students wearing the veil' despite the fact that prohibitions resulted in the denial of education for Leyla Sahin and many other Turkish women. ${ }^{36}$ The Court also referred to what it perceived to be the wide margin of appreciation of the states in this area, in concluding that measures were proportionate. These considerations (under Art 9) were also held applicable in respect of the right to education, and hence the Court found no violation of that right, despite affirming its importance (as discussed in a number of international documents) and the need for interpretation in a way that renders it practical and effective. The Grand Chamber also looked at the discrimination claim. It dismissed it without too much consideration on account of the prohibition not being directed against the applicant's religious affiliation, following its unsympathetic approach to indirect discrimination, as in Dahlab. that, from 1998 to 2000, some 25,000 women were barred from college campuses in Turkey because they refused to remove their headscarves. Several hundred government employees were fired, dismissed or transferred for the same reason. See Salbiah Ahmad, 'Europe: Unveiling of Religious Discrimination' 29 July $2004<$ http://www.wluml.org/english/newsfulltxt.shtml?cmd $\% 5 B 157 \% 5 \mathrm{D}=\mathrm{x}-157-62673>$. For a critique of the Court's conclusion, see also Judge Tulken's dissenting opinion to the Grand Chamber judgment (n 26).
} 


\section{Analysis of the cases}

While Dahlab v Switzerland and Leyla Sahin v Turkey concern different categories of applicants and different social contexts, there were some common themes, and some common characteristics of the Court's reasoning in these cases. In both cases, the Court accepted that interference with the applicants' rights was 'necessary in democratic society' for the protection of the rights of others and of public order. In both cases it referred to the importance of the principles of religious neutrality/secularism and the principles of gender equality to safeguard the rights of others and for public order, accepting the states' interpretation of these principles, referring to their assessment of what was necessary in the context of their society.

The difference was that in Dahlab the prohibition was mainly justified by the principle of denominational neutrality in primary state school and the protection of young children from undue religious influences in view of their 'tender' age. In this case, gender equality was referred to only in once sentence. In Sahin, the prohibition was mainly justified by the principle of secularism (as a constitutional order) and the protection of the rights of women (who do not wear headscarves). Here, the principle of gender equality played a prominent role. In addition, in Sahin great emphasis was given to the particular historical context of Turkey, and the facts that the majority of the population adhere to the Muslim faith and that there were 'extremist political movements in Turkey. ${ }^{37}$

\subsection{Secularism, denominational neutrality of the state, the context and margin of appreciation}

In both cases it was argued by the government that the prohibitions were necessary to safeguard the principles of the separation of state and religion, secularism, and the denominational neutrality of the state and state education institutions, which served for the protection of religious plurality and thereby respect of the rights and freedoms of others. These claims raised the question of the relationship of religion and the state, religion and international human rights law, and the principle of secularism/neutrality.

International human rights law does not mandate any specific relationship between the state and religion; it only mandates the protection of freedom of religion (and other human rights). ${ }^{38}$ Operating in religiously

\footnotetext{
37 N 26115.

38 While the freedom to hold religious beliefs is absolute, the manifestation of religion can be restricted, in accordance with law and when necessary in a democratic society.
} 
and culturally diverse worlds, ${ }^{39}$ it starts from the premise that a variety of socio-political orders exist that are, in principle, capable of guaranteeing human rights. ${ }^{40}$ However, it accepts (and promotes) the separation of state and religion (neutrality/secularism) as a good model conducive to protecting religious freedoms.

This is also the approach of the Court. The Court has frequently emphasised the state's role as a neutral and impartial organiser of the exercise of various religions, faiths and beliefs, and has stated that this role is conductive to public order, religious harmony and tolerance in democratic society. ${ }^{41}$ On the other hand, it has held that:

...where questions concerning the relationship between state and religions are at stake on which opinion in a democratic society may reasonably differ, the role of the national decision-making body must be given special importance in view of the diversity of practices. This will notably be the case when it comes to regulating the wearing of religious symbols in education institutions, especially in view of the diversity of the approaches taken by national authorities on the issue. The choice of the extent and form such regulations should take must inevitably be left up to the state and it will depend on the context. ${ }^{42}$

Hence, states have a certain margin of appreciation in regulating the relationship between religion and the state, and, as part of this question, the wearing of religious dress in school. Nevertheless, the margin of appreciation is not supposed to be unlimited: 'it goes hand in hand with a European supervision. ${ }^{43}$ The scope of the margin is generally narrower where there is consensus among member states and where fundamental interests are at stake.

However, in these cases the Court's supervision was minimal, even though fundamental interests were at stake: the applicants' rights to participate in society, through education and employment, with respect accorded to their religious precepts. Moreover, with regard to the bans on

\footnotetext{
39 There are religion-based states, states with an established religion, secular states and anti-religious states.

40 The relationship between human rights and religion is complex, stirring many debates, among which universalism v cultural relativism. Religion-based states which condition their acceptance of international human rights obligations on compatibility with Islamic law pose a particular problem for international human rights law. However, secularism might also be problematic, particularly in respect of guaranteeing the freedom to manifest religion in the public space. See McGoldrick (n 3) 22-28. See also M. Freeman, 'The Problem of Secularism in Human Rights Theory' (2004) 26(2) Human Rights Quarterly 375.

$41 \quad$ N 26107.

42 Ibid 109.

43 Ibid.
} 
headscarves imposed on students, there was consensus on the free choice of dress for university students, with Turkey being the only country to impose prohibitions. ${ }^{44}$ The Court did not really scrutinise the challenged measures, deferring almost completely to the states' interpretation of the principles of neutrality/secularism and gender equality.

For example, in Dahlab, the Court accepted that the denominational neutrality of the state and its education institutions is necessary in order to respect pupils' and their parents' religious beliefs and to prevent religious conflicts, but it did not really discuss what its requirements are. Religious pluralism could have arguably been respected by allowing everybody, including teachers, to freely manifest their beliefs in a non-aggressive manner. This could even better serve the idea of pluralism, as it might enhance children's understanding of diversity and difference. As noted by the German Constitutional Court in the similar case of Lund, it is not at all so obvious that children are easily influenced by teachers' manifestation of religion; there is insufficient data to indicate any harmful influence of the headscarf on children. ${ }^{45}$ Indeed, the applicant in Dahlab argued that no impact could be shown, and that the principle of secularism in school only demands that teaching be independent of faith, but does not prevent teachers from manifesting their religious beliefs. Moreover, Swiss secularism anyhow did not prohibit teachers from wearing all religious symbols, since 'discrete religious symbols' such as small pieces of jewellery were allowed, a fact which was neglected by the Court.

Similarly, the Court did not discuss the meaning of secularism and its requirements in respect of the religious dress of students in Sahin. The closest it came to discussing what secularism means was when it mentioned the principle of neutrality with regard to religion, and the separation of religious and public spheres. The Court accepted that Turkish secularism exhibits these two features, while many have claimed that Turkish secularism does not respect either. For example, the Special Rapporteur on freedom of religion and belief has criticised the 'secularism' of Turkey on the grounds, inter alia, that the state is implicated in religious affairs by promoting a particular version of Islam, and hence discriminating against other Muslim and non-Muslim religious communities. ${ }^{46}$

In addition, the Court did not discuss whether strict separation between public and religious spheres was acceptable from the perspective of respect for religious freedoms. For example, the German Constitutional Court held in the Lund case that opening the sphere of the state for

\footnotetext{
44 See the Dissenting Opinion of Judge Tulkens to the Grand Chamber Judgment (n 8). 45 N 7.

46 See Interim Report of the Special Rapporteur of the Commission on Human Rights on the elimination of all forms of intolerance and discrimination based on religion or belief, Add 1 Situation in Turkey, UN Doc A/55/280/Add 1 (2000).
} 
religions in principle, though with certain limits, allows 'far more liberty than strict exclusion,' distinguishing between neutrality so defined and laicism. ${ }^{47}$ It seems that the Court did not consider the need to respect students' religious beliefs as a requirement of secularism, contrary to the way the principle was perceived in Dahlab. Neither did the Court consider the link between secularism and the military regime in Turkey. ${ }^{48}$ In that respect, it is interesting to note that in Dahlab the government stated that militant secularism does not meet the requirements of neutrality.

Neither of these questions was explored, despite their relevance for the 'particularities' of the Turkish context to which the Court constantly referred as a key factor. It only took two factors to constitute the relevant context: that the majority of the population was Muslim, and that there was a rise in Islamic fundamentalism. Even then, it did not explore the links between the applicant's wearing of the headscarf and these factors. Neither did the Court explore the question of the effectiveness of the measure to curb fundamentalism, and whether 'insistence on separating their [Muslim] ideals from the country where they live' might be likely to increase, rather than decrease, separatism and fundamentalism. ${ }^{49}$

\subsection{Gender equality}

As mentioned above, in both cases reference was made to gender equality as justification for the prohibitions of wearing headscarves. In Leyla Sahin, the principle was given greater significance, and it was the rights of women that the Court saw in need of protection. In Dahlab, the principle was also referred to at one instance, where it was noted that "wearing the headscarf is hard to square with the principle of gender equality', but the case was not discussed in terms of protection of the rights of women, but primarily in terms of protection of the rights of children. ${ }^{50}$ However, unlike Lelya Sahin, Dahlab argued sex discrimination. ${ }^{51}$

48 TJ Gunn 'Fearful Symbols: The Islamic Headscarf and the European Court of Human Rights' (2005) Conference paper <http://www.strasbourgconference.org/papers/ Sahin\%20by\%20Gunn\%2021\%2 0by\%20T.\%20Jeremy\%20Gunn.pdf $>$.

49 N Walter, 'When the Veil Means Freedom - Respect Women's Choices that are not Our Own, Even if they Include Wearing the Hijab' The Guardian, 20 January 2004. See also J Freedman, 'Secularism as a Barrier to Integration? The French Dilemma' (2004) 43(3) International Migration 5. See also reactions to the Leyla Sahin judgment in the Turkish on-line journal <www.zaman.org $>$.

50 This link is actually interesting. Women with children are often classified in law as in need of special protection.

51 L Sahin also argued discrimination, but on the basis of religion. The Court [GC] held that prohibition was not directed against the applicant's religious affiliation, but pursued, among other things, the legitimate aim of protecting the rights of others and public order.
} 
As regard the alleged goal of protecting the rights of women in Sahin, the Court did not discuss how the applicant's actions threatened women's rights, or how the principle could justify prohibiting an adult woman from following what seemed a freely adopted and personally important practice, which did not appear to harm anyone..$^{52}$ It also did not explore the consequences which the prohibition would have for the applicant ${ }^{53}$ and thousands of other women in Turkey who would not be able to access education. ${ }^{54}$ It thus seemed that the Court excluded Leyla and other women who wear Islamic headscarves from the category of women whose rights and equality need to be protected.

On the other hand, when Dahlab claimed violation of her rights as a woman, the Court dismissed her claim on account of the measure not being directed against her as a female. The disparate impact on Muslim women who consider it their religious duty to wear the headscarf, and the disadvantage they suffer on that account, was not sufficient to constitute prima facie discrimination. ${ }^{55}$ However, such reasoning denies protection against indirect, unintentional forms of discrimination: 'myriad ways in which dominant standards and more systemic forms of discrimination in our society, which are at face value neutral, tend to disadvantage or

Hence, the Court does not see the prohibitions as discriminatory on the basis of religion or sex, even though the prohibitions clearly have a disparate impact on Muslim women. This shows the Court's lack of understanding of the intersectionality of discrimination.

52 The applicant claimed that she was not pressured into wearing the headscarf, but considered it her religious duty. Moreover, she explicitly stated that she did not aim to influence other women to wear it.

53 Leyla Sahin felt strong enough about veiling to take the case to the Court and to move to Vienna to study. Not only did the ban prevent her from studying in Turkey, but it may have prevented her from living in Turkey, as she would not be able to practise medicine there. This has not only hurt her but also Turkish society.

54 As noted by Human Rights Watch, the judgment denies education and a career to a significant number of Turkish women who wear the headscarf. See Human Rights Watch, 'Memorandum to the Turkish Government on Human Rights Watch's Concerns with Regard to Academic Freedom in Higher Education, and Access to Higher Education for Women Who Wear the Headscarf 29 June 2004 <http://hrw.org/backgrounder/eca/turkey/2004/ headscarf_memo.pdf>; Turkey: Headscarf Ruling Denies Women Education and Career' 16 November $2005<$ http://hrw.org/english/docs/2005/11/16/turkey12038.htm>. See also Jonathn Sudgen (HRW Turkey researcher) ‘A Certain Lack of Empathy', 1 July 2004 $<$ http://www.zaman.com.tr/webapp-tr/haber.do?haberno=65002 $>$. This judgment might also alienate Muslims, which could result in an increase in fundamentalism, which will be played out on women's bodies.

55 The measure could be challenged (by teachers, university staff or civil servants as employees) as indirect discrimination under EU 2000 Directive on Equal Treatment in Employment and Occupation (Council Directive 2000/78/EC of 27 November 2000). Blair and Aps have argued that, in the UK context, a prohibition on a teacher wearing the jilbab would probably always raise a prima facie case of indirect discrimination. See A Blair and W Aps, 'What Not to Wear and Other Stories: Addressing Religious Diversity in Schools' (2005) $17(1 / 2)$ Education and the Law 1. 
exclude members of less powerful groups. ${ }^{56}$ Moreover, the Court's focus on potential restrictions on the religious dress of men is in denial of the reality that it is Muslim women, and not Muslim men, ${ }^{57}$ who wear a "visible religious symbol'- the headscarf. Moreover, the applicant took as a comparator Muslim men, while the Court changed this to any men.

The Court's application of the principle of gender equality in the 'Islamic headscarf' cases was simplistic and paternalistic. The ruling displays a lack of sensitivity to difference, including cultural and religious identity, and fails to consider the intersectionality of discrimination. ${ }^{58}$ In interpreting gender equality, the Court dismissed the perspective of those affected, and failed to examine the distinct harms that Muslim women who wear the 'Islamic headscarf' suffer (both imposed by their communities and the state), and the consequences that the prohibitions would have on them. In dismissing the perspectives of the woman in question, the Court pitted the principle of gender equality against the principle of personal autonomy, to the latter of which it generally gives great value. ${ }^{59}$

The Court started from the assumption that wearing the headscarf is an oppressive patriarchal practice which connotes the submission of women to men and the control of their sexuality, which can never be freely chosen, while research shows that the practice has a more complex meaning (for both wearer and observer), which depends on many different factors, including status and power relations in society. ${ }^{60}$ For example,

\footnotetext{
56 T Loenen and PR Rodriguez, Non-Discrimination: Comparative Perspectives (Martinus Nijhoff, The Hague 1999) 199.

57 It might be on account of this that the Court changed the comparator from 'Muslim men' to 'men'.

58 The concept of intersectionality of discrimination refers to the interrelatedness of the different systems of oppression. It was first developed by feminists of colour: see, eg, Crenshaw, 'Demarginalizing the Intersection of Race and Sex: A Black Feminist Critique of Antidiscrimination Doctrine, Feminist Theory and Anti-Racist Politics' [1989] University of Chicago Legal Forum 139. For the intersection of discrimination based on sex and sexual orientation, see, eg, Cane, 'Feminist Jurisprudence: Grounding the Theories' (1989) 4 Berkeley Women's Law Journal 191.

59 The Court's reasoning was thus in conflict with the Court's case law on the right to personal autonomy. Moreover, it was in conflict with its case law on religious freedom and freedom of expression. Finally, the Court's interpretation of the requirement that the prohibition is based in law, its use of the doctrine of the margin of appreciation (in particular consensus), its emphasis on the particularity of the general societal context, rather than on individual injustice and the facts of the case, and its acceptance of restrictions on fundamental individual rights on the basis of hypothetical rather than real threats for the community as proportionate, even when those restrictions undermine the essence of the right to education are in conflict with the Court's general approach to interpretation. See the Dissenting Opinion of Judge Tulkens to the Grand Chamber judgment (n 3). See also J Marshall, 'Freedom of Religious Expression and Gender Equality: Sahin v Turkey' (2006) 69 MLR 452.

60 See, eg, D Lyon and D Spini, 'Unveiling the Headscarf Debate' (2004) 12 Feminist Legal Studies 333; L Abu-Odeh, 'Post-colonial Feminism and the Veil' (1993) 43 Feminist Review
} 
some women claim that wearing a veil is an act of submission not to men but to God. Others claim that wearing the veil actually promotes, rather than undermines, their dignity and protects them from unwanted sexual advances and objectification. ${ }^{61}$ Yet others see it as a way of expressing identity and an act of resistance to the anti-Muslim policies of the West which have been on the increase since $9 / 11 .{ }^{62}$ However, the Court completely neglected these aspects of the intersection of identity and systems of discrimination and the particular context of discrimination against Muslims. Instead, it focused on the headscarf's proselytising effect and on its alleged link with Islamic fundamentalism. ${ }^{63}$ Indeed, it seems that the Court was more concerned with the rise of Islamic fundamentalism (in predominantly Christian Europe) than with gender equality.

While the issue of Islamic fundamentalism (or any other religious/ ideological fundamentalism) and its consequences for women's rights is not to be undermined, the way the Court linked the wearing of the headscarf and (the hypothetical threat of fundamentalism in order to justify the prohibition on grounds of gender equality is dubious. Moreover, while the practice of veiling is problematic from the perspective of women's rights, since one of its (many) meanings certainly connotes (sexual) control and the submission of women, and certainly violates women's human rights when it is forced on women, wholesale state prohibitions are not the appropriate answer.

This does not mean that the state should remain passive, as it has obligations to take steps to "eliminate prejudices and other practices based on the idea of the inferiority and superiority of either of the sexes or on stereotyped roles for women and men which are implicated in at least some practices of veiling, ${ }^{64}$ The state should thus take measures to empower women from these communities by securing their education (including education on women's rights) and employment opportunities, and by fighting the gender and racial/religious discrimination that they face. However, measures which restrict women's education and employment opportunities are difficult to reconcile with the agenda of gender

26; D McGoldrick, Human Rights and Religion: The Islamic Headscarf Debate in Europe (Hart Publishing, Oxford 2006). For the meaning of the veil in the Turkish context, see AJ Secor, 'The Veil and Urban Space in Istanbul' (2002) 9 Place and Culture 5.

61 The fundamental question is rather whether women should change their clothing in order not to be 'attractive', or whether men should change their (sexually harassing) behaviour.

62 For discussions by Muslim women on the meaning they assign to veils, see $<$ http:// www.metafilter.com/mefi/46875>.

63 See the Grand Chamber judgment (n 26) 115.

64 The Convention on the Elimination of All Forms of Discrimination against Women Convention (adopted 18 December 1979, entered into force 3 September 1981) 1249 UNTS 13 art 5(b). 
equality understood as a challenge to women's disempowerment and disadvantage.

The 'liberation of women' is hardly to be achieved by further restricting their already restricted choices. Dealing with one set of constraints (imposed by community/family) by imposing another (through state prohibitions) hardly seems a logical answer, especially when it can result in severe consequences for the women in question, including their further exclusion and marginalisation. While the prohibition allegedly aims to allow women to compete in public spheres and institutions on purportedly equal terms with men, free from the private, patriarchal restrictions of 'fundamentalist' fathers, brothers, husbands, etc, it may result in closing public spheres to women who are forced to wear the veil, or who find it their religious or community duty to wear it. Prohibitions could thus be counterproductive, and result in women not leaving their homes, rather than leaving their veils at home. ${ }^{65}$

Moreover, as Judge Tulkens stated, in what can be described as a 'different voice', ${ }^{66}$ 'if wearing the headscarf really was contrary to the principle of gender equality, then the Court should have imposed on States the positive obligation to prohibit it in private places as well' ${ }^{67}$ Prohibiting the veil only in the public sphere, while allowing it in the private, is not an effective way to stop the practice. The Court's assumption that there was a way to reconcile freedom of religion and gender equality by regulating religion in the private sphere, and gender equality in the public sphere, was unwarranted.

Gender equality cannot be achieved if it is respected only in the public sphere, nor can religion be relegated to the private sphere, because religious expression is inherently social. As Sunder argued, the construction of the private/public dichotomy in international human rights law, according to which the religious sphere is characterised by a lack of reason and equality, while the public sphere is characterised by (en-

\footnotetext{
65 On the other hand, it has been reported that some Muslim women and families found the French law of 2004 prohibiting the headscarf in schools to be a liberating experience: Sage, 'The Headscarf Ban is Judged Success as Hostility Fades' The Times 5 September 2005, cited in McGoldrick (n 3) 270-275.

66 While other judges engaged in what could be described as 'the ethics of justice' in defining relevant rights and principles in an abstract manner, without reference to the particular situation of the applicant, and then balancing them in a hierarchical manner (gender equality versus freedom of religion), Judge Tulkens reasoned in an 'ethics of care' mode. She was sensitive to the applicant's situation (as constituted by her different identity characteristics and her relationships in society), and was concerned to find a solution which would 'harmonise the principles of secularism, equality and liberty, not... weigh one against the other' para 4 of her Dissenting Opinion. The idea of a 'different voice' was developed by Carol Gilligan in her book In a Different Voice: Psychological Theory and Women's Development (1982).

67 Dissenting Opinion of Judge Tulkens (n 26) 12.
} 
lightened) reason and equality, does not provide meaningful choices for women within religious communities. ${ }^{68}$ International human rights law has to find a way out of the dichotomy to provide women with meaningful freedom: freedom within identity, rather than freedom outside identity and community, while simultaneously empowering them to change identities and their communities. The cases at issues failed to do so.

\section{Conclusion}

Prohibitions on wearing the Islamic headscarf in education institutions raise a number of complicated questions. Among them are respect for religious freedoms and of gender equality, and the role of the state and international human rights law in safeguarding them (and the functional division between the state and international institutions). These were the questions the European Court faced in Leyla Sahin v Turkey and Dahlab $v$ Switzerland. However, rather than trying to answer them, the Court referred to the state's interpretation of these principles, emphasising the state's primary role in safeguarding them.

In both cases, the Court affirmed the bans on the headscarf (imposed on teachers in state primary schools and on university students), holding that the state has a right, in the name of gender equality and the principle of secularism, to impose restrictions on wearing the headscarf due to its 'proselytising effect' and the threat it poses to public order and to the rights and freedoms of others in the context of the facts of the cases. By leaving the issue within the state's margin of appreciation, the Convention organs might have hoped to stay clear of the complex political and legal debate. However, by affirming the ban on the grounds of the principles of gender equality and secularism, the Court has been implicated in the debate not only on Islamic headscarves, but on the principle of gender equality and secularism, in a manner that has significant negative consequences for (Muslim) women in view of its powerful position as an international human rights court.

68 See M Sunder, 'Piercing the Veil' (2003) 112 Yale Law Journal 1399. 